Vol 2, No 1, Juni 2021; 65-75

e-ISSN : 2723-3324

Available at: e-journal.sttberitahidup.ac.id/index.php/jan/index

\title{
Pendidikan Keluarga Kristen dalam Mencegah Kenakalan Remaja
}

\author{
Marten Malo Nono ${ }^{1}$ \\ marten.yulis@gmail.com
}

\begin{abstract}
Christian Family Education is a God-centered education and is based on Biblical teaching. According to Deuteronomy 6:6-9, education is done by continuously teaching God's word. Christian family education is also directed education with excellent educational methods to do and apply in Christian families. Education in Christian families is needed to deal with juvenile delinquency. Based on the explanation above, it is necessary to develop regular education in the family through formal and non-formal theological education, hold regular retreats for Christian families, hold regular fellowships between family members, and build prayer altars at home to strengthen fellowship between family members and increasingly active in providing family members with regular and repeated Bible education and study.
\end{abstract}

Keywords: Christian family education; Deuteronomy 6:6-9; juvenile delinquency

\begin{abstract}
Abstrak
Pendidikan Keluarga Kristen adalah pendidikan yang berpusat pada Allah dan dasar pengajarannya yang Alkitabiah. Menurut kitab Ulangan 6:6-9 adalah pendidikan dilakukan dengan terus menerus mengajarkan firman Tuhan. Pendidikan keluarga Kristen juga merupakan pendidikan terarah dengan metode pendidikan yang sangan baik untuk di lakukan dan di terapkan dalam keluarga Kristen. Diperlukan pendidikan dalam keluarga Kristen untuk menanggulangi kenakalan anak remaja. Berdasarkan penjelasan di atas, maka perlu dikembangkan pendidikan secara rutin dalam keluarga melalui pendidikan teologi secara formal maupun nonformal, mengadakan retret secara berkala bagi keluarga Kristen, mengadakan persekutuan yang rutin antar anggota keluarga, dan membangun mazbah doa di rumah untuk mempererat persekutuan antar anggota keluarga dan semakin giat untuk memperlengkapi anggota keluarga dengan pendidikan dan pendalaman Alkitab secara rutin dan berulang-ulang.
\end{abstract}

Kata-kata kunci: pendidikan keluarga Kristen; Ulangan 6:6-9; kenakalan remaja

\section{PENDAHULUAN}

Pendidikan Kristen adalah pendidikan yang berpusat pada Allah, suatu implikasi dalam interpretasi kasih Allah. ${ }^{2}$ Pendidikan dalam keluarga Kristen adalah pendidikan di

\footnotetext{
${ }^{1}$ Mahasiswa Pascasarjana Sekolah Tinggi Teologi Berita Hidup

${ }^{2}$ Khoe Yao Tung, Filsafat Pendidikan Kristen (Yogyakarta: Andi, 2013), 263.
} 
mana Allah berperan untuk membentuk anak-anak yang dikaruniakan Allah kepada keluarga, agar bertumbuh dalam iman dan memiliki nilai-nilai kekristenan dalam kehidupan sehari-harinya.

Menurut Hardi Budiyana, pendidikan keluarga Kristen adalah bantuan yang dilakukan dengan sadar atau sengaja kepada anak-anak agar supaya mereka bertumbuh dan berkembang mencapai kedewasaan secara sosial dan nilai-nilai kekristenan atas dasar iman Kristen. ${ }^{3}$ Selanjutnya menurut Julianto Simanjuntak, pendidikan Kristen yang sehat di dalam keluarga akan menghasilkan keturunan yang tangguh, kedewasaan mental dan psikologis anak terbentuk dengan baik. ${ }^{4}$ Kemudian Jakob D. Engel mengatakan bahwa fungsi gereja adalah untuk memelihara atau mengasuh, yakni memampukan keluarga Kristen untuk mengembangkan potensi-potensi sehingga tercipta pendidikan Kristen yang baik dalam keluarga. ${ }^{5}$ Hal ini dikatakan oleh Kalis Stevanus bahwa penggembalaan di gereja oleh hamba-hamba Tuhan dapat membantu menyelesaikan masalah-masalah keluarga, dalam hal ini memberikan pengajaran dan pendampingan tentang pendidikan Kristen dalam keluarga. ${ }^{6}$ Dari beberapa pendapat di atas gereja memiliki peranan penting untuk menolong menyelenggarakan pendidikan Kristen dengan baik sehingga menghasilkan keturunan yang tangguh, kedewasaan mental dan psikologis anak terbentuk dengan baik.

\section{METODE}

Penelitian ini menggunakan metode deskriptif dengan pendekatan penelitian kepustakaan. Di mana peneliti berusaha menjawab permasalahan penelitian dengan mencari sumber-sumber literatur yang berkorelasi dengan masalah penelitian. Kemudian peneliti menganalisis sumber-sumber yang berkait dengan menggunakan analisis isi yang merupakan kajian yang menitikberatkan interpretasi bahan tertulis berdasarkan konteksnya untuk mendapatkan jawaban atas masalah penelitian.

\section{PEMBAHASAN}

\section{Pengertian Pendidikan Keluarga Kristen secara Umum}

Pengertian pendidikan menurut Kamus Besar Bahasa Indonesia adalah proses pengubahan sikap dan tata laku seseorang atau kelompok orang dalam usaha mendewasakan

\footnotetext{
${ }^{3}$ Hardi Budiyana, Dasar-dasar Pendidikan Agama Kristen, Cetakan ke. (Surakarta: STT Berita Hidup, 2017), 5.

${ }^{4}$ Julianto Simanjuntak, Pintu-pintu Kehidupan (Tangerang: Peduli Konseling Nusantara, 2011), 3.

${ }^{5}$ Jacob D. Engel, Konseling suatu Fungsi Pastoral (Salatiga: Tisara Grafika, 2007), 8.

${ }^{6}$ Kalis Stevanus, Cekcok tetapi Sudah Cocok (Salatiga: Widya Sari Press, 2012), 62-63.
} 
manusia melalui upaya pengajaran dan pelatihan; proses cara; perbuatan pendidik. $^{7}$ Selanjutnya Lois E Lebar mengatakan bahwa pendidikan adalah usaha sadar yang membuat bergairah, penuh semangat dan sukacita dalam menjalani kehidupan ini.

Kemudian hal yang senada disampaikan oleh Hardi Budiyana bahwa pendidikan adalah usaha sadar untuk mendorong siswa mengalami peristiwa belajar di dalam hidupnya. Pendidikan sebagai usaha sadar dan bersahaja, senantiasa menempatkan manusia sebagai subjek sebab manusialah pelaku pendidikan. Kemudian menurut Ditjen Dikti dalam Buku Dasar-dasar Pendidikan dikatakan bahwa pendidikan adalah proses di mana seseorang mengembangkan kemampuan sikap dan bentuk-bentuk tingkah laku lainnya di dalam masyarakat di mana ia hidup, proses sosial di mana orang dihadapkan pengaruhi lingkungan, khususnya lingkungan sekolah sehingga dia dapat memperoleh atau mengalami pengembangan kemampuan sosial dan individu yang optimum. ${ }^{8}$ Dilanjutkan oleh Robert W. Pazmino bahwa pendidikan adalah perencanaan, implementasi dan evaluasi terhadap pengalaman- pengalaman edukasional yang berpengaruh dalam pengembangan kemampuan. ${ }^{9}$ Ditambahkan oleh Junihot Simanjuntak bahwa pendidikan sebagai usaha bersengaja, sistematis dan terus-menerus untuk menyampaikan, menimbulkan dan memperoleh pengetahuan, sikap-sikap, nilai-nilai, keahlian-keahlian atau kepekaankepekaan, juga setiap akibat dari usaha itu. ${ }^{10}$ Berdasarkan pengertian pendidikan di atas peneliti dapat menyimpulkan bahwa pendidikan adalah usaha sadar dan sengaja dengan senantiasa mendewasakan manusia melalui upaya perencanaan pengajaran dan pelatihan; proses, yang bersistematis dan terus menerus menyampaikan, menimbulkan dan memperoleh pengertian, nilai-nilai, sikap-sikap dan implementasi serta evaluasi terhadap pengalaman-pengalaman edukasional yang diusahakan.

Keluarga menurut Kamus Besar Bahasa Indonesia (KBBI) adalah lembaga yang terkecil dari masyarakat yang terdiri atas kepala keluarga dan beberapa orang yang terkumpul dan tinggal di suatu tempat di bawah suatu atap dalam keadaan saling ketergantungan. ${ }^{11}$ Sedangkan menurut Marulak Pasaribu keluarga adalah sebagai satu unit keluarga yang terdiri dari pasutri dan anak-anaknya disebut sebagai 'a nuclear family' (keluarga inti). ${ }^{12}$ Senada dengan Hardi Budiyana yang mengatakan bahwa keluarga adalah

\footnotetext{
7 "Pendidikan" https://kbbi.web.id/pendidik. diakses pada tgl 12 Desember 2019

${ }^{8}$ Tim Pengadaan Buku Pelajaran, Dasar-dasar Pendidikan (Semarang: IKIP Semarang, 1991), 2.

${ }^{9}$ Robert W. Pazmino, Pondasi Pendidkan Kristen (Jakarta: BPK Gunung Mulia, 2018), 22.

${ }^{10}$ Junihot Simanjuntak, Psikologi Pendidikan Agama Kristen (Yogyakarta: Penerbit Andi, 2016), 4.

11 "Keluarga" https://kbbi.kemdikbud.go.id diakses pada tgl 12 Desember 2019

${ }^{12}$ Marulak Pasaribu, Prinsip-Prinsip Dasar Pernikahan dan Keluarga Bahagia (Malang: Gandum
} Mas, 2020), 4. 
unit dasar dalam masyarakat dan keluarga adalah batu penjuru di mana di atasnya segala sesuatu dibangun. ${ }^{13}$

Keluarga Kristen menurut Hardi Budiyana adalah pemberian Tuhan yang tak ternilai harganya. ${ }^{14}$ Kemudian dilanjutkan oleh Hardi Budiyana bahwa keluarga Kristen adalah tempat untuk belajar bagaimana menyesuaikan diri, tempat untuk belajar bagaimana mengatasi masalah, belajar bagaimana mengasihi satu dengan yang lain, hidup sesuai dengan Firman Tuhan, hidup dalam kekudusan, disiplin untuk mencapai kedewasaan iman, bersukacita senantiasa dan murah hati, lemah lembut dan ramah dengan pertolongan Roh Kudus. ${ }^{15}$ Dilanjutkan dalam buku Petunjuk Guru Madya dikatakan bahwa keluarga Kristen adalah tempat untuk saling mengasihi satu sama lainnya, sebagai wadah atau tempat untuk belajar berbuat baik sebagai keluarga Allah yang menjadi berkat bagi orang lain. ${ }^{16}$ Keluarga Kristen adalah keluarga yang menerima baptisan dari Allah Bapa, Allah Anak, dan Roh Kudus. Segala tindakan-tindakan dalam keluarga Kristen berpatokan pada Pengajaran Tuhan Yesus.

Definisi pendidikan Keluarga Kristen adalah usaha sadar dan sengaja yang di lakukan oleh orang tua untuk memberikan pembentukan dan penanaman nilai-nilai kekristenan berlandaskan Alkitab sebagai pedoman, berpusat pada Kristus, dan bergantung kepada kuasa Roh Kudus yang membimbing setiap anggota keluarga untuk bertumbuh ke arah pengenalan akan Kristus sebagai Guru Agung yang mendewasakan setiap orang percaya. ${ }^{17}$ Selanjutnya Julianto Simanjuntak mengatakan bahwa pendidikan keluarga Kristen memiliki sumber nilai yang mutlak yaitu Firman Allah, dengan demikian setiap keluarga Kristen harus di letakkan di atas dasar Yesus Kristus dan bersumber pada Firman Tuhan (1Kor. 3:6-7). ${ }^{18}$ Kemudian Paul Gunadi mengatakan bahwa Pendidikan Keluarga Kristen adalah pendidikan yang tidak sekedar memberikan pengajaran tetapi keteladanan hidup yang berdasarkan pada Firman Allah sebagai sumber pengajaran dengan pertolongan Roh Kudus. ${ }^{19}$ Berdasarkan definisi di atas maka peneliti menyimpulkan bahwa pendidikan keluarga Kristen adalah usaha sadar dan sengaja yang di lakukan oleh orang tua berdasarkan Alkitab sebagai pedoman, berpusat pada Kristus dengan pertolongan Roh Kudus agar

\footnotetext{
${ }^{13}$ Budiyana, Dasar-dasar Pendidikan Agama Kristen, 248.

${ }^{14}$ Ibid., 272.

${ }^{15}$ Ibid., 274.

${ }^{16}$ Petunjuk Guru Madya (Malang: Gandum Mas, n.d.), 25.

${ }^{17}$ Budiyana, Dasar-dasar Pendidikan Agama Kristen, 9-10.

${ }^{18}$ Julianto Simanjuntak, Merekayasa Lingkungan Anak (Bandung: Kalam Hidup, 2014), 25.

${ }^{19}$ Gunadi, Andrew Abdi Setiawan, dan Lortha Mahanani, Memahami Remaja Putri dan Pergumulannya (Bandung: Visi Anugerah Indonesia, 2015), 30.
} 
bertumbuh ke arah pengenalan akan Kristus sebagai Guru Agung yang mendewasakan setiap orang percaya, pengajaran yang berpatokan dengan keteladanan hidup atas pertolongan Roh Kudus.

\section{Peranan Orang Tua Dalam Keluarga Kristen}

Di bawah ini peneliti akan membahas tentang peranan orang tua dalam keluarga Kristen, di antara lain sebagai berikut:

\section{Menuntun Anggota Keluarga Bertumbuh Secara Rohani}

Orang tua mempunyai tanggung jawab atau peranan dalam pertumbuhan rohani anggota keluarganya. Marulak Pasaribu mengatakan bahwa orang tua dalam hal ini seorang ayah bertanggungjawab dalam keluarganya yakni bertanggungjawab dalam hal rohani, bertanggungjawab dalam hal sosial dan bertanggungjawab dalam hal ekonomi. Orang tua bertanggungjawab dengan masalah pertumbuhan rohani anggota keluarganya dan berfungsi sebagai imam dalam keluarga (Kej. 12:8; Ayub 1:5). ${ }^{20}$ Selanjutnya Daniel Alexander mengatakan bahwa orang tua mempunyai peranan penting dalam membekali dan mendorong anggota keluarga agar bertumbuh terus dalam iman untuk menghadapi serangan musuh yaitu iblis. ${ }^{21}$ Sedangkan menurut Julianto Simanjuntak mengatakan bahwa orang tua harus melatih anggota keluarga untuk mengembangkan kemampuan agar tetap semangat dalam berdoa supaya dapat membantu atau menasihati orang lain dan membawa orang lain kepada Tuhan. ${ }^{22}$ Berdasarkan paparan di atas maka peneliti dapat menyimpulkan bahwa orang tua mempunyai peranan yang sangat penting dalam pertumbuhan baik pertumbuhan secara iman atau rohani maupun dalam mengembangkan kemampuan dalam hal berdoa supaya dapat membantu atau menasihati orang lain untuk kembali kepada Tuhan.

\section{Membentuk Karakter Anggota Keluarga}

Karakter dalam Kamus Besar Bahasa Indonesia adalah tabiat, sifat-sifat kejiwaan, akhlak atau budi pekerti yang membedakan seseorang dengan yang lain; watak. ${ }^{23}$ Selanjutnya menurut B.S. Sidjabat karakter atau watak adalah sifat, tabiat atau kebiasaan dalam diri dan dalam kehidupan kita, yang sudah begitu tertanam dan berurat berakar serta telah menjadi ciri khas diri sendiri (personilitas). ${ }^{24}$ Dalam hal ini yang dapat berperan dalam membina dan Membentuk karakter adalah orang tua. Charles F. Boyd mengatakan bahwa

\footnotetext{
${ }^{20}$ Pasaribu, Prinsip-Prinsip Dasar Pernikahan dan Keluarga Bahagia, 18.

${ }^{21}$ Daniel Alexander, Pemulihan Keluarga Masa Kini (Yogyakarta: Andi, 2001), 38.

${ }^{22}$ Julianto Simanjuntak, Psikologi Pendidikan Agama Kristen (Yogyakarta: Andi, 2016), 60-70.

23 “Karakter" https://kbbi.web.id/karakter. diakses pada tgl 13 Desember 2019

${ }^{24}$ B.S. Sidjabat, Membangun Pribadi Unggul (Yogyakarta: Andi, 2011), 1-2.
} 
orang tua yang sudah memenuhi syarat sebagai pemimpin atau pejabat gereja adalah harus tahu dan mampu mengatur keluarganya dengan baik, dan mendidik anak-anaknya untuk taat dan hormat baik kepada pribadinya sebagai kepala keluarga maupun kepada Tuhan sebagai pemimpin utama dalam keluarga Kristen. ${ }^{25}$ B.S. Sidjabat menambahkan bahwa selaku sebagai orang tua dalam keluarga memiliki peranan dan tanggung jawab yang sangat penting dalam membentuk karakter dan kepribadian anak dan mampu ,membawa anggota keluarga untuk mengalami pertumbuhan iman. ${ }^{26}$

Berdasarkan uraian di atas maka peneliti menyimpulkan bahwa membentuk karakter anggota keluarga yang dimaksudkan membentuk karakter merupakan tindakan orang tua untuk membentuk karakter atau tabiat dari pada anggota keluarga agar menjadi anak-anak yang taat dan hormat kepada orang tua itu sendiri maupun kepada Tuhan serta mengalami pertumbuhan iman atau rohaninya setiap hari.

\section{Menjamin Kebutuhan Anggota Keluarga}

Pada dasarnya orang tua tidak terlepas dari sebuah tanggung jawab dalam memenuhi kebutuhan hidup anggota keluarganya. Adapun kebutuhan anggota keluarga adalah sebagai berikut.

Kebutuhan Rohani. salah satu peranan orang tua adalah memperhatikan kebutuhan rohani terhadap anggota keluarganya. Menurut Marulak Pasaribu dalam buku Prinsipprinsip Dasar Pernikahan Dan Keluarga Bahagia mengatakan bahwa orang tua yang menjadi pemimpin atau imam dalam keluarga tetap dalam bertanggungjawab untuk mendidik dan melatih anggota keluarga untuk beriman kepada Tuhan (Yeh. 12:3, 26:27; Ams. 22:6; Ef. 6:4). ${ }^{27}$ Orang tua yang takut akan Tuhan akan menjadi pengarah rohani dalam keluarga. Chang Khui Fa mengatakan bahwa orang tua yang takut akan Tuhan, dan setia menjalankan peranannya untuk mengarahkan rohani keluarganya, terbukti anak-anak perlahan-lahan menjadi takut akan Tuhan dan mencintai Firman-Nya. ${ }^{28}$ Anak yang takut akan Tuhan sejak dini membuat orang tua tidak mengkhawatirkan masa depan anggota keluarganya.

Selain orang tua bertanggungjawab kepada anggota keluarganya akan kebutuhan rohani, orang tua juga bertanggungjawab terhadap Kebutuhan ekonomi bagi anggota keluarganya. Orang tua dalam hal ini seorang ayah diharapkan untuk menyediakan kebutuhan yaitu kebutuhan jasmani bagi anggota keluarganya. Orang yang malas akan gagal

${ }^{25}$ Charles F. Boyd, Menyikapi Perilaku Anak Sesuai Dengan Karekternya (Bandung: Kalam Hidup, 2006), 158.

${ }^{26}$ Ibid., 75.

${ }^{27}$ Ibid., 18.

${ }^{28}$ Khui Fa Chang, Garam Dan Terang Bagi Keluarga (Malang: Pionir Jaya, 2009), 50-51. 
untuk mencukupi kebutuhan keluarganya (Ams. 6:6-11) dan Rasul Paulus mengecam orang percaya yang tidak memperhatikan kebutuhan anak-anak dengan berkata "Tetapi jika ada seorang yang tidak memelihara sanak saudaranya, apalagi seisi rumahnya, orang itu murtad dan lebih buruk dari orang yang tidak beriman (1Tim. 5:8). ${ }^{29}$ Chang Khui Fa menjelaskan bahwa orang tua yang takut akan Tuhan adalah orang yang tahu dan mengerti tanggung jawabnya yaitu orang tua yang berkorban bagi kehidupan dan kebutuhan keluarganya. ${ }^{30}$ Selanjutnya Marulak Pasaribu mengatakan bahwa seorang ayah berperan bukan hanya sekedar sebagai kepala keluarga tetapi juga sekaligus menjadi imam dalam keluarga, ia menjadi orang yang bertanggungjawab dalam kehidupan rohani seluruh anggota keluarga, ia harus memelihara altar keluarga dan mengatur persembahan kepada Allah. ${ }^{31}$

Berdasarkan paparan di atas maka peneliti dapat menyimpulkan bahwa sebagai orang tua harus menjamin kebutuhan keluarga di mana orang tua bertanggungjawab untuk mendidik dan melatih anggota keluarga untuk beriman kepada Tuhan sampai anak-anak dan anggota keluarga menjadi takut akan Tuhan dan orang tua harus berkorban untuk mencukupi kebutuhan jasmani dan rohani keluarganya.

\section{Melindungi Anggota Keluarga}

Dalam Kamus Besar Bahasa Indonesia kata Melindungi adalah menjaga, merawat, memelihara, menyelamatkan (memberi pertolongan dan sebagainya) supaya terhindar dari mara bahaya seperti contoh induk ayam yang melindungi anaknya terhadap serangan burung elang. ${ }^{32}$ Selanjutnya Suharti mengatakan bahwa orang tua berhak melindungi anggota keluarganya dari serangan musuh, yang berusaha menghancurkan masa depan anggota keluarga. ${ }^{33}$ Kemudian B.S. Sidjabat mengatakan bahwa orang tua tidak hanya mencukupi kebutuhan anggota keluarganya, tetapi juga orang tua mempunyai peranan untuk memberikan pendampingan berdasarkan teladan Tuhan yang menyertai dan memampukan orang percaya. ${ }^{34}$ Berdasarkan pengertian di atas maka peneliti dapat menyimpulkan bahwa melindungi memiliki pengertian menjaga, merawat, memelihara, menyelamatkan agar terhindar dari bahaya atau melindungi anak atau anggota keluarga dari serangan musuh dan terus memberikan pendampingan berdasarkan teladan dari Tuhan yang mampu untuk melindungi anggota keluarga.

\footnotetext{
29 Ibid., 18.

${ }^{30}$ Ibid., 47-48.

${ }^{31}$ Pasaribu, Prinsip-Prinsip Dasar Pernikahan dan Keluarga Bahagia, 18.

32 “melindungi” https://kbbi.kata.web.id/melindungi. diakses pada tgl 22 Januari 2020

${ }^{33}$ Sidjabat, Membangun Pribadi Unggul, 8.

${ }^{34}$ Ibid., 177.
} 


\section{Memberikan Kasih Sayang Kepada Anggota Keluarga}

Amsal 3:12 "Karena Tuhan memberi ajaran kepada yang dikasihi-Nya, seperti seorang ayah kepada anak yang disayangi". Ayat ini menunjukkan betapa pentingnya peran seorang ayah sebagai kepala keluarga yang menjadi teladan bagi anggota keluarganya. Kasih sayang merupakan sebuah rasa yang timbul dan tulus dari hati untuk menyayangi, mencintai, memberi kebahagiaan kepada seseorang tanpa rasa pamrih sedikit pun dan menghitung apa yang telah kita lakukan kepada orang lain. ${ }^{35}$ Danang Baskoro mengatakan bahwa menyayangi keluarga atau anak adalah sangat baik dalam mengaktualisasikan kasih Allah dalam kehidupan sehari-hari terlebih khusus dalam kehidupan keluarga. ${ }^{36}$ Marulak Pasaribu mengatakan bahwa kasih adalah sebagai suatu tindakan atau perbuatan yang mendatangkan kemuliaan bagi Tuhan. ${ }^{37}$ itu sebabnya sebagai orang tua harus mampu memberikan cinta dan kasih sayang kepada anggota keluarga. Cinta atau kasih memiliki porsi yang paling utama dalam kehidupan manusia.

Josh Weidmam mengatakan bahwa anak atau anggota keluarga tidak membutuhkan kasih sayang yang hanya kata-kata melainkan mereka membutuhkan kasih sayang dari orang tua kepala keluarga lewat tindakan dan perbuatan. ${ }^{38}$ kemudian James Dobson mengatakan bahwa orang tua harus mampu menunjukkan keteladanan dalam mengaktualisasikan kasih Allah dalam keluarga sekalipun di tengah-tengah kesibukan dengan sedikit memberikan perhatian dan waktu bersama anggota keluarga sebagai bentuk kasih sayang. ${ }^{39}$ Kehadiran orang tua dalam keluarga rupanya sangat penting dan teramat penting untuk memberikan sedikit kenyamanan bagi anggota keluarga, itulah sebabnya orang tua sebagai kepala anggota keluarga merupakan tempat berlindung yang aman bagi anak atau anggota keluarga. ${ }^{40}$

Berdasarkan pengertian di atas maka peneliti dapat menyimpulkan bahwa salah satu peranan orang tua dalam anggota keluarga adalah memberikan rasa yang timbul dengan tulus dari hati untuk menyayangi, mencintai, memberi kebahagiaan kepada anggota keluarga tanpa rasa pamrih sedikit pun untuk mengaktualisasikan kasih Allah lewat tindakan dan

35 “Kasih Sayang Orang Tua Pada Anak" https://nuqtoh.com/kasih-sayang/\# . Diakses pada tgl 14 Desember 2019

${ }^{36}$ Danang Baskoro, Menjadi Lebih Baik (Parent Healing) (Jakarta: Elex Media Komputindo, 2014), 25 .

${ }^{37}$ Pasaribu, Prinsip-Prinsip Dasar Pernikahan dan Keluarga Bahagia, 8. 2006), 49.

${ }^{38}$ Josh Weidmam dan Jim Weidmam, Ayah Aku Ingin Bicara (Yogyakarta: Gloria Usaha Mulia,

${ }^{39}$ James Dobson, Masalah Membesarkan Anak (Bandung: Kalam Hidup, 2005), 21.

${ }^{40}$ Ibid., 32. 
perbuatan dan memberikan perhatian dan waktu serta kehadiran orang tua karena orang merupakan tempat berlindung yang aman bagi anggota keluarga.

\section{Pendidikan Keluarga Kristen dalam Mencegah Kenakalan Remaja}

Kenakalan remaja atau Juvenile Delinquency adalah suatu perbuatan yang melanggar norma-norma, aturan atau hukum dalam masyarakat yang dilakukan pada usia remaja, kenakalan remaja juga dikenal sebagai penyimpangan perilaku dengan berpartisipasinya seorang remaja dalam perbuatan yang menimbulkan keonaran dalam masyarakat. ${ }^{41}$ Selanjutnya Nenden mengatakan bahwa kenakalan remaja adalah merupakan tingkah laku yang melampaui batas toleransi orang lain atau lingkungan sekitar serta suatu tindakan yang dapat melanggar norma- norma dan hukum yang hidup di dalam masyarakat. ${ }^{42}$ Senada dengan Sumiati mengatakan bahwa kenakalan remaja adalah suatu perilaku yang di lakukan oleh remaja dengan mengabaikan nilai-nilai sosial yang berlaku di dalam masyarakat, kenakalan remaja meliputi semua perilaku menyimpang dari norma-norma dan hukum yang dilakukan oleh remaja dan perilaku tersebut dapat merugikan diri sendiri maupun orang- orang di sekitarnya. ${ }^{43}$ Sedangkan Kartono mengatakan bahwa kenakalan remaja atau Juvenile delinquency merupakan gejala patologi sosial pada remaja yang di sebabkan oleh satu bentuk pengabaian sosial, akibatnya remaja mengembangkan perilaku yang menyimpang. ${ }^{44}$ Kemudian menurut Sunarwiyati S (dalam Nenden, 2010:29) membagi tiga kenakalan remaja yakni kenakalan biasa, kenakalan yang menjurus pada pelanggaran kejahatan dan kenakalan khusus yang berujung pada penyalahgunaan narkotika, hubungan seks di luar nikah, pemerkosaan dan lain-lain. ${ }^{45}$

Jadi berdasarkan penjelasan di atas maka peneliti menyimpulkan bahwa kenakalan remaja adalah suatu perbuatan atau tindakan yang menyimpang dan ilegal yang melampaui batas toleransi orang lain atau lingkungan sekitar serta suatu tindakkan yang dapat melanggar norma-norma hukum yang berlaku di dalam masyarakat serta dapat mengakibatkan kerugian dan kerusakan baik terhadap dirinya sendiri maupun orang lain yang di sekitarnya. kenakalan remaja memiliki jenis berbeda yaitu jenis-jenis kenakalan remaja, akibat kenakan remaja, faktor-faktor kenakalan remaja dan cara mengatasi kenakalan remaja.

\footnotetext{
${ }^{41}$ Siegel dan Welsh, Juvenile Delinquency: The Core, 4 ed. (New York: Cengage Learning, 2013).

${ }^{42}$ Nenden Rilla Artistiana, Penyakit Penyimpangan Sosial (Bogor: Regina Eka Utama, 2010), 25.

${ }^{43}$ D Sumiati, Kesehatan Jiwa Rxemaja dan Konseling (Jakarta: Trans Indo Media, 2009), 54.

${ }^{44}$ Kartini Kartono, Psikologi Patologi 2 Kenakalan Remaja (Jakarta: Rajawali Press, 1998), 187.

${ }^{45}$ Ibid., 29.
} 
Pendidikan keluarga Kristen merupakan kunci penting dalam menanggulangi kenakalan remaja. Dalam rumah tangga Kristen, orang tua mempunyai peranan penting dan sangat berpengaruh dalam perkembangan serta pembentukan remaja, itu sebabnya pendidikan dalam rumah tangga keluarga Kristen menjadi tolak ukuran dalam pembekalan nilai-nilai Kristiani bagi remaja. Pola pendidikan keluarga Kristen dalam dokumentasi kitab Ulangan 6:6-9 adalah penerapan pendidikan dan pengajaran yang sangat jelas yakni orang tua berperan mengajarkan Firman Tuhan berulang-ulang atau terus menerus kepada anakanak remaja.

\section{KESIMPULAN}

Dalam keluarga, orang tua berperan menuntun anggota keluarga bertumbuh secara rohani, membentuk karakter anggota keluarga, menjamin kebutuhan anggota keluarga, melindungi anggota keluarga, dan memberikan kasih sayang kepada anggota keluarga. Bila hal ini terwujud, anak-anak remaja dari keluarga tersebut akan dicegah dari kenakalan. Maka perlu dikembangkan pendidikan secara rutin dalam keluarga melalui pendidikan teologi secara formal maupun nonformal, mengadakan retret secara berkala bagi keluarga Kristen, mengadakan persekutuan yang rutin antar anggota keluarga, dan membangun mazbah doa di rumah untuk mempererat persekutuan antar anggota keluarga dan semakin giat untuk memperlengkapi anggota keluarga dengan pendidikan dan pendalaman Alkitab secara rutin dan berulang-ulang.

\section{REFERENSI}

Alexander, Daniel. Pemulihan Keluarga Masa Kini. Yogyakarta: Andi, 2001.

Artistiana, Nenden Rilla. Penyakit Penyimpangan Sosial. Bogor: Regina Eka Utama, 2010. Baskoro, Danang. Menjadi Lebih Baik (Parent Healing). Jakarta: Elex Media Komputindo, 2014.

Boyd, Charles F. Menyikapi Perilaku Anak Sesuai Dengan Karekternya. Bandung: Kalam Hidup, 2006.

Budiyana, Hardi. Dasar-dasar Pendidikan Agama Kristen. Cetakan ke. Surakarta: STT Berita Hidup, 2017.

Chang, Khui Fa. Garam Dan Terang Bagi Keluarga. Malang: Pionir Jaya, 2009.

Dobson, James. Masalah Membesarkan Anak. Bandung: Kalam Hidup, 2005.

Engel, Jacob D. Konseling suatu Fungsi Pastoral. Salatiga: Tisara Grafika, 2007.

Gunadi, Andrew Abdi Setiawan, dan Lortha Mahanani. Memahami Remaja Putri dan

Pergumulannya. Bandung: Visi Anugerah Indonesia, 2015.

Kartono, Kartini. Psikologi Patologi 2 Kenakalan Remaja. Jakarta: Rajawali Press, 1998.

Khoe Yao Tung. Filsafat Pendidikan Kristen. Yogyakarta: Andi, 2013.

Pasaribu, Marulak. Prinsip-Prinsip Dasar Pernikahan dan Keluarga Bahagia. Malang:

Gandum Mas, 2020.

Pazmino, Robert W. Pondasi Pendidkan Kristen. Jakarta: BPK Gunung Mulia, 2018. 
Sidjabat, B.S. Membangun Pribadi Unggul. Yogyakarta: Andi, 2011.

Siegel, dan Welsh. Juvenile Delinquency: The Core. 4 ed. New York: Cengage Learning, 2013.

Simanjuntak, Julianto. Merekayasa Lingkungan Anak. Bandung: Kalam Hidup, 2014.

—. Pintu-pintu Kehidupan. Tangerang: Peduli Konseling Nusantara, 2011.

. Psikologi Pendidikan Agama Kristen. Yogyakarta: Andi, 2016.

Simanjuntak, Junihot. Psikologi Pendidikan Agama Kristen. Yogyakarta: Penerbit Andi, 2016.

Stevanus, Kalis. Cekcok tetapi Sudah Cocok. Salatiga: Widya Sari Press, 2012.

Sumiati, D. Kesehatan Jiwa Rxemaja dan Konseling. Jakarta: Trans Indo Media, 2009.

Tim Pengadaan Buku Pelajaran. Dasar-dasar Pendidikan. Semarang: IKIP Semarang, 1991.

Weidmam, Josh, dan Jim Weidmam. Ayah Aku Ingin Bicara. Yogyakarta: Gloria Usaha Mulia, 2006.

Petunjuk Guru Madya. Malang: Gandum Mas, n.d. 